\title{
Characterization of lactic acid bacteria isolated from poultry farms in Senegal
}

\author{
Coulibaly Ibourahema ${ }^{1 *}$, Robin Dubois Dauphin ${ }^{1}$, Destain Jacqueline ${ }^{1}$ and Philippe Thonart ${ }^{1,2}$ \\ ${ }^{1}$ Centre wallon de Biologie Industrielle (CWBI), Unité de Bio-industries, Faculté Universitaire des Sciences \\ Agronomiques de Gembloux (FUSAGx), Passage des Déportés 2, B-5030 Gembloux, Belgium. \\ ${ }^{2}$ Centre wallon de Biologie Industrielle (CWBI), Service de Technologie Microbienne, université de liège (ULg), Sart \\ Tilman, B40, B-4000 Liège, Belgium.
}

Accepted 16 May, 2008

\begin{abstract}
The group that includes the lactic acid bacteria is one of the most diverse groups of bacteria known and these organisms have been characterized extensively by using different techniques. In this study, thirty lactic acid bacterial strains were isolated from soils chicken faeces and feathers. A total of nineteen isolates were obtained and by sequential screening for catalase activity and Gram-staining, eight were determined to be LAB out of which six were established to be homofermentative by the gel plug test. Five isolates were identified by use of the API 50CHL kit and four Lactobacilli strains and one Lactococci strain were selected to study their growth and lactic acid production profiles in a time course experiment. The Lactobacilli strains, both isolated from faeces, produced higher amounts of cells and lactic acid from soils as compared to the lactococci strain isolated from feathers. $L(+)$-lactic acid is the only optical isomer for use in pharmaceutical and food industries because is only adapted to assimilate this form. The optical isomers of lactic acid were examined by $L(+)$ and $D(-)$ lactate dehydrogenase kit. Lactobacilli strains produced combination of both optical isomers of lactic acid. Among them, Lactobacillus casei subsp. casei produced the low amount of D (-)-lactic (2\%). The optimum rates of glucose for lactic acid production by Lactobacillus strains were 180 and $120 \mathrm{~g} / \mathrm{l}$ for Lactobacillus plantarum and Lactobacillus paraplantarum, respectively.
\end{abstract}

Key words: Characterization, lactic acid bacteria, Lactobacillus, L (+)-lactic acid, D (-)-lactic acid, optical isomers.

\section{INTRODUCTION}

The isolation and screening of microorganisms from natural sources has always been the most powerful means for obtaining useful and genetically stable strains for industrially important products. Lactic acid bacteria (LAB) are important in the food and dairy industries because the lactic acid and other organic acids produced by these bacteria act as natural preservatives as well as flavour enhancers. LAB find increasing acceptance as probiotics which aid in stimulating immune responses, preventing infection by enteropathogenic bacteria, and treating and preventing diarrhoea (Reid, 1999). LAB is a

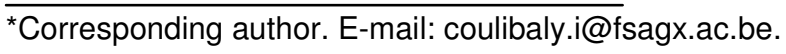

diverse bacterial group consisting of 11 genuses. These bacteria are Gram-positive, non-spore-forming cocci or rods which produce lactic acid as their main metabolic product. Lactobacilli are found in a variety of habitats, also in the gastrointestinal (GI) tract of human. Lactic acid bacteria have a long history as GRAS (generally regarded as safe) organisms and especially members of genus Lactobacillus, Lactococcus and Streptococcus are widely used in fermentation industry. Several species of genus Lactobacillus have been used in food products as probiotic organisms. Probiotic strains are selected for potential application on the basis of particular physiological and functional properties. Since generalizations about the probiotic performance of species cannot be yet made based on scientific evidence, it is more reliable to assume that probiotic properties are strain-specific (San- 
ders et al., 1999). In non-food applications, lactic acid is the building blocks used in the chemical polymerisation of poly lactic acid (PLA), a biodegradable and biocompatible material which is a good alternative to synthetic plastics.

Lactic acid could be produced by chemical synthesis, e.g., as a by-product in the petrochemical industries, or it could be made by microbial fermentation. The fermentation process is becoming more relevant because the raw materials used in fermentation are renewable in contrast to petrochemicals (Kharras et al., 1993). Furthermore, the fermentation process could produce optically pure isomers of lactic acid. Pure isomers, L (+) or D (-) - lactic acid, are more valuable than the racemic DL form because each isomer has its own applications in the cosmetics and pharmaceuticals industries. In PLA, the ratio of $L(+)$ and $D(-)$ - lactic acid influences the degradability of the polymers (Kharras et al., 1993); therefore it is easier to manufacture PLA with specific properties, e.g., degradability, if $L(+)$ and $D(-)$ - lactic acid are supplied separately. LAB that have industrial potential should be homofermentative, i.e., they produce only lactic acid. The lactic acid bacteria (LAB) are of major economic and nutritional importance because of their use in the production and preservation of a many variety of fermented products. In particular, species closely related to the Lactobacillus group are increasingly used as adjunct cultures in milk fermentations (Mayra-Makinen et al., 1998).

Much current research is focused on characterizing their industrially relevant traits and the opportunities for strain improvement by metabolic engineering (Gasson, 1993; de Vos, 1997; Mollet, 1999). Lactic acid bacteria are characterized as Gram-positive, usually non-motile, non- sporulating bacteria that produce lactic acid as a major or sole product of fermentative metabolism. Kandler and Weiss have classified Lactobacillus isolates from temperate regions according to their morphology, physiology and molecular characters (Kandler et al., 1986). Schleifer classified LAB based on the molecular characteristics (Schleifer et al., 1987). LAB from food and their current taxonomical status have been described by many (Gonzalez et al., 2000; Ringoe and Gatesoupe, 1998; Schleifer, 1987; Stiles and Holzapfel, 1997). Taxonomic studies on LAB from African animals are rare. Molecular methods are important for bacterial identification (Drancourt et al., 2001; Greetham et al., 2003; Sghir et al., 2000 ) and possibly more accurate for LAB than are conventional phenotypic methods. The objective of this study was to isolate lactic acid bacteria from chicken faeces and poultry soils and to screen these isolates for desirable traits such as homofermentative ability, production of isomeric form lactic acid, and tolerance to high concentration of lactic acid, low $\mathrm{pH}$ and high temperature.

\section{MATERIALS AND METHODS}

\section{Isolation of lactic acid bacteria strains 6}

Soils and faeces samples were collected from different poultry farms in Dakar (Senegal, West Africa). Strains isolation was carried out according to Nakayama and Yanoshi (1967). Five grams of sample were mixed with $100 \mathrm{ml}$ of GYP medium contained $1 \%$ glucose $(\mathrm{w} / \mathrm{v}), 1 \%$ yeast and $1 \%$ peptone. The sample suspendsion was heated for $10 \mathrm{~min}$ at $80^{\circ} \mathrm{C}$ and incubated anaerobically at $30^{\circ} \mathrm{C}$. After $48 \mathrm{~h}$ of incubation, $100 \mu \mathrm{l}$ of the mixture were spread onto the surface of GYP agar containing $1 \% \mathrm{CaCO}_{3}$. The culture was incubated anaerobically at $30^{\circ} \mathrm{C}$. Acid producing bacteria were recognised by the clear zones around the colonies. Bacteria were purified by several isolations and fresh cultures of these isolates were conserved at $-80^{\circ} \mathrm{C}$ with glycerol $(30 \%)$ as cryoprotective agents (Saw et al., 2004). Each of the isolates was first tested for catalase by placing a drop of $3 \%$ hydrogen peroxide solution on the cells. Immediate formation of bubbles indicated the presence of catalase in the cells. Only those isolates which were catalasenegative were Gram-stained, and only those which were Grampositive were put through the gel plug test (Gibson and AbdelMalek, 1945) to determine whether the isolate produced carbon dioxide during fermentation. An isolate was deemed to be a homofermentative lactic acid producer if no gas was produced. Based on the results, five homofermentative isolates were selected for further studies. These isolates were identified by the API $50 \mathrm{CHL}$ identification kit (BioMérieux, Marcy-l'Etoile, France).

\section{Determination of lactic acid isomers}

Bacterial cell concentration was determined at $610 \mathrm{~nm}$ and calibrated into colony forming units (CFU) by colony count method and into dry mass weight (Siebold et al., 1995). Bacterial cell concentration was determined by dry mass weight (Vaccari et al., 1993; Monteagudo et al., 1997). The dry mass weight of bacterial and fungal cells was determined by centrifugation of the fermentation broth and freeze-dried sediments (Monteagudo et al., 1997). The concentration of lactic acid was measured based on colorimetric determination by $L(+)$ and $D(-)$-lactate dehydrogenase kit (Megazyme International Ireland Ltd., Co. Wicklow, IRELAND). In this method, known amounts of production medium were taken during fermentation and centrifuged at $3000 \times \mathrm{g}$ for $10 \mathrm{~min}$. The supernatant was used directly for determination of lactic acid concentration. The assays are specific for either D-lactic acid or Llactic acid. In the assay of lithium D-lactate $(\mathrm{MW}=96.0)$ results of approx. $96 \%(\mathrm{w} / \mathrm{w})$ can be expected, while a value of $98 \%(\mathrm{w} / \mathrm{w})$ should be obtained with lithium L-lactate. The smallest differenttiating absorbance for the assay is 0.005 absorbance units. This corresponds to $0.107 \mathrm{mg} / \mathrm{L}$ of sample solution at the maximum sample volume of $1.50 \mathrm{~mL}$ (or to $1.60 \mathrm{mg} / \mathrm{L}$ with a sample volume of $0.1 \mathrm{~mL}$ ). The absorbance of the solutions (A1) was read against blank at $340 \mathrm{~nm}$ (Beckman Coulter, spectrometer AD 340s) after approx. $3 \mathrm{~min}$ and the reactions were initiated by addition of $0.02 \mathrm{ml}$ of $(\mathrm{D}-\mathrm{LDH}) /(\mathrm{L}-\mathrm{LDH})$ suspensions and then the second absorbances of the solutions (A2) were read at the end of the reaction (approx. $20 \mathrm{~min}$ ). In situations where the reaction did not stop after $20 \mathrm{~min}$, the absorbances were read at 5 min intervals until the absorbance either remains the same, or increases constantly over $5 \mathrm{~min}$. The $\mathrm{D}$ $(-)$ and $L(+)$-lactic acid were also determined by enzyme test kit according to the manufacturer's instruction (Megazyme International Ireland Ltd).

\section{Assay of residual glucose}

Consumption of glucose during cultivation is measured at the end of fermentation. The diluted supernatant as above was also used for the assay of residual glucose. After centrifugation, the supernatant was collected for analysis. The determination of glucose in the supernatant was measured by using an analyzer of sugar, 
Table 1. Some characteristics of the five homofermentative $L A B$, isolated from poultry farms in Senegal.

\begin{tabular}{|c|l|l|l|c|c|}
\hline $\begin{array}{c}\text { Isolate } \\
\text { name }\end{array}$ & $\begin{array}{c}\text { Origin from which } \\
\text { isolated }\end{array}$ & $\begin{array}{c}\text { Cell } \\
\text { morphology }\end{array}$ & $\begin{array}{c}\text { Identification by } \\
\text { API 50CHL kit }\end{array}$ & $\begin{array}{c}\text { Identification } \\
\text { Probabilities (\%) }\end{array}$ & $\begin{array}{c}\text { Lactic acid isomer } \\
\text { produced }\end{array}$ \\
\hline Spo03 & Fleachers & Rod & Lactobacillus casei & 97,6 & $\mathrm{~L}(+)$ \\
Spo05 & Fresh intestine & Cocci & Lactococcus lactis & 98,5 & $\mathrm{~L}(+)$ \\
Spo11 & soils & Rod & Lactobacillus plantarum & 99,8 & $\mathrm{D} / \mathrm{L}$ \\
Spo04 & soils & Rod & Lactobacillus plantarum & 99,8 & D/L \\
Spo20 & Chicken faeces & Rod & Lactobacillus paraplantarum & 99,9 & D/L \\
\hline
\end{tabular}

YSI2700 SELECT (Yellow Springs Instrument Co., Inc.).

\section{Effect of temperature, $\mathrm{pH}$, lactic acid and sodium chloride}

A basal MRS medium was used in these series of studies (de Man et al., 1960) but without beef extract, and with $0.15 \mathrm{~g} / \mathrm{l}$ bromocresol purple added as $\mathrm{pH}$ indicator $(\mathrm{pH} 7)$. A lowering of this $\mathrm{pH}$ would change the medium from purple to yellow, and was taken to indicate cell growth because the production of lactic acid is growthrelated. No change in the colour of the medium was taken to indicate no cell growth because no acids were released. Universal bottles with screw caps were each filled with $20 \mathrm{ml}$ of the basal MRS medium and autoclaved. An $18 \mathrm{~h}$ culture of each isolate was used as the inoculum whereby the cells were spun down, resuspended in $0.85 \%$ saline, and $100 \mu \mathrm{l}$ of the suspension was inoculated into each test bottle. The temperatures tested were 15 , $30,37,44$ and $55^{\circ} \mathrm{C}$, the concentrations of lactic acid tested were 3 , $5,7,5,9$ and $12 \%(\mathrm{w} / \mathrm{v})$, and the concentrations of $\mathrm{NaCl}$ tested were $1.5,2.5,5,7.5$ and $10 \%(\mathrm{w} / \mathrm{v})$. Four $\mathrm{pH}$ were tested, i.e., 4, 5.5, 7 and 9. The basal MRS medium was adjusted with $1 \mathrm{M}$ phosphoric acid and $1 \mathrm{M} \mathrm{NaOH}$ to prepare this initial $\mathrm{pH}$. The bottles were placed in water baths with reciprocal shaking, set at the specific test temperatures or at $37^{\circ} \mathrm{C}$ for the tests on $\mathrm{pH}$ and concentrations of lactic acid and $\mathrm{NaCl}$. At the end of $42 \mathrm{~h}$, the colour changes and turbidity of each bottle was noted as a simple indication of growth or no-growth. Each treatment was tested with triplicate bottles.

\section{Determination of turbidity}

The biomass evolution was followed by using the turbidimetrical method (the optical density: OD) at $540 \mathrm{~nm}$. Acidity of the culture media was measured by titration with $0.5 \mathrm{~N} \mathrm{NaOH}$ using phenolphthalein as $\mathrm{pH}$ indicator.

\section{RESULTS AND DISCUSSION}

\section{Screening of lactic acid bacteria}

Thirty bacterial isolates were obtained from the poultry farms in Senegal (Dakar) and glucose was used in the enrichment medium. Of these, 25 tested Gram-positive and catalase-negative, and all but one was rod-shaped. The one remaining $L A B$ isolate was coccus-shaped. Fifteen of these isolates did not produce gas in the gel plug test and were, therefore, deemed to be homofermenters. Based on the origin which the isolate was obtained, five of these 15 were selected for characterization and the tolerance tests. Table 1 lists these five isolates, giving details about the food origin, according to the substrate used in the enrichment process (sugar), cell morphology, and identification by the API 50CHL kit, probability of fit to the closest species, and the type of lactic acid isomer produced. The isolate from feathers regardless of the sugar used in the enrichment medium, were identified as Lactobacillus casei, while the isolate from soils was identified as Lactobacillus plantarum. The isolate obtained from fresh intestine was identified as Lactobacillus lactis. Isolates identified as $L$. case $i$ and $L$. lactis produced only the L-form of the lactic acid while the isolate identified as $L$. plantarum produced a mixture of $D$ and $L$ isomers of lactic acid. $L A B$ strains that produce a single isomeric form of lactic acid are more desirable as industrial strains compared to those strains that produce a racemic mixture of lactic acid. This is because the material properties of poly (lactic acid) are governed by the ratio of $L$ and $D$ isomers in the polymer, so the polymerization process would be better controlled when the lactic acid used as starting material is in single isomeric forms.

\section{Tolerance to high temperatures, concentrations of lactic acid and sodium chloride, and low pH}

Table 2 shows the tolerance of each of the five selected isolates to the environmental conditions tested. Three strains of the Lactobacillus sp. grew at 15 to $44^{\circ} \mathrm{C}$, while the isolated from feathers, Spo03, could not grow at $15^{\circ} \mathrm{C}$. The Lactococcus, Spo5, isolated from fresh chiken's intestine grew at higher temperatures ranging from 30 to $44^{\circ} \mathrm{C}$ with no growth indicated at $15^{\circ} \mathrm{C}$. Wouters et al. (2000) noted reduced glycolytic activity leading to reduced production of lactic acid in L. lactis at low temperature. The ability to grow at high temperature is a desirable trait as it could translate to increased rate of growth and lactic acid production. At the same time, a high fermentation temperature reduces contamination by other microorganisms. Spo05, however, was the least tolerant to high concentrations of lactic acid as growth was indicated only at 2 and not at $5 \%$ and higher. The two isolates from soils and chicken faeces, Spo4 and Spo20 respectively, were the most tolerant of high lactic acid concentrations as they were able to grow at $7.5 \%$. The other one isolate from soils Spo11 could tolerate up to $5 \%$ lactic acid concentration. None of the five isolates 
Table 2. Tolerance of the five $L A B$ isolates to ranges of temperatures, lactic acid, $\mathrm{NaCl}$ concentrations and $\mathrm{pH}$.

\begin{tabular}{|c|c|c|c|c|c|}
\hline \multirow[b]{2}{*}{ Environmental conditions } & \multicolumn{5}{|c|}{ Isolate name } \\
\hline & Spo03 & Spo05 & Spo11 & Spo04 & Spo20 \\
\hline \multicolumn{6}{|l|}{ Temperature } \\
\hline $15^{\circ} \mathrm{C}$ & - & - & + & + & + \\
\hline $30^{\circ} \mathrm{C}$ & + & + & + & + & + \\
\hline $37^{\circ} \mathrm{C}$ & + & + & + & + & + \\
\hline $44^{\circ} \mathrm{C}$ & + & + & + & + & + \\
\hline $55^{\circ} \mathrm{C}$ & - & - & - & - & - \\
\hline \multicolumn{6}{|c|}{ Lactic acid concentration (\%, w/v) } \\
\hline 3.0 & + & + & + & + & + \\
\hline 5.0 & + & - & + & + & + \\
\hline 7.5 & - & - & - & + & + \\
\hline 9.0 & - & - & - & - & - \\
\hline 12 & - & - & - & - & - \\
\hline \multicolumn{6}{|l|}{$\mathrm{NaCl}$ concentration $(\%, w / v)$} \\
\hline 1.5 & + & + & + & + & + \\
\hline 2.5 & + & + & + & + & + \\
\hline 5.0 & + & + & + & + & + \\
\hline 7.5 & - & + & - & - & - \\
\hline 10 & - & - & - & - & - \\
\hline \multicolumn{6}{|l|}{ pH (End point) } \\
\hline 4.0 & + & - & + & + & + \\
\hline 5.5 & + & - & + & + & + \\
\hline 7.0 & + & + & + & + & + \\
\hline 9.0 & + & + & + & + & - \\
\hline
\end{tabular}

+ Indicates colour change from purple to yellow, taken to equate growth; - indicates no colour change from purple, taken to equate no growth.

grew at 9 and $12 \%$ lactic acid concentrations. A higher tolerance to lactic acid is a desirable trait for an industrial strain of LAB as it could produce more lactic acid in the fermentation broth without prematurely affecting itself adversely. In contrast to its low tolerance to lactic acid, Spo5 was the most tolerant to high $\mathrm{NaCl}$ concentration compared to the other isolates. Spo5 grew in concentrations up to $7.5 \%$ while the rest could grow up to $5 \%$. None of the isolates could grow in $7.5 \% \mathrm{NaCl}$. This test gave an indication of the osmotolerance level of a $\mathrm{LAB}$ strain. Bacterial cells cultivated in a high salt concentration would experience a loss of turgor pressure, which would then affect the physiology, enzyme activity, water activity and metabolism of the cells (Liu et al., 1998). Some cells overcome this effect by regulating the osmotic pressure between the inside and outside of the cell (Kashket, 1987). There are reports describing strains of Lactococci (Uguen et al., 1999) and Lactobacilli (Hutkins et al., 1987; Glaasker et al., 1998) showing decreased growth rate with increasing osmolarity of the medium. Uguen et al. (1999) also noted increased amount of glycine betaine, an osmolyte, in lactococci cells when they were grown in high $\mathrm{NaCl}$ concentration. Liu et al. (1998) reported that the uptake of glycine betaine was induced in cells as an adaptive measure to withstand increasing external osmotic pressure. The lactococci isolate, Spo5, could be similarly protected to be able to grow at higher $\mathrm{NaCl}$ concentration compared to the other isolates which were lactobacilli. During industrial fermentation, as lactic acid is being produced by the cells, alkali would be pumped into the broth to prevent excessive reduction in $\mathrm{pH}$. Thus, the free acid would be converted to its salt form which would in turn increase the osmotic pressure on the cells. Therefore, a LAB strain with high osmotolerance would be desirable as an industrial strain. All the isolates, except Spo5, could grow at $\mathrm{pH} 5.5$. The inability of Spo5 to grow at low $\mathrm{pH}$ was consistent with its inability to grow at high lactic acid concentration, and was attributed to the low tolerance of L. lactis to free acid $(\mathrm{H}+)$ compared to Lactobacillus spp. (Kashket, 1987). LAB are acidophilic but while that means a tolerance to low $\mathrm{pH}$, the latter should be differentiated from a situation in which a high concentration of free acids $(\mathrm{H}+)$ also exists because the free 


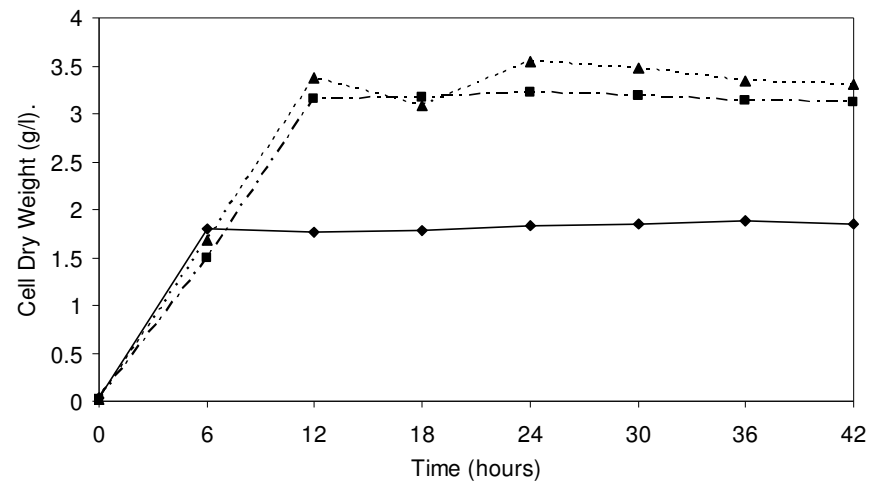

Figure 1. Biomass produced by three strains of Lactobacilli: ( $\downarrow)$ Spo05, (匹) Spo04 and (A) Spo20 isolates over $42 \mathrm{~h}$.

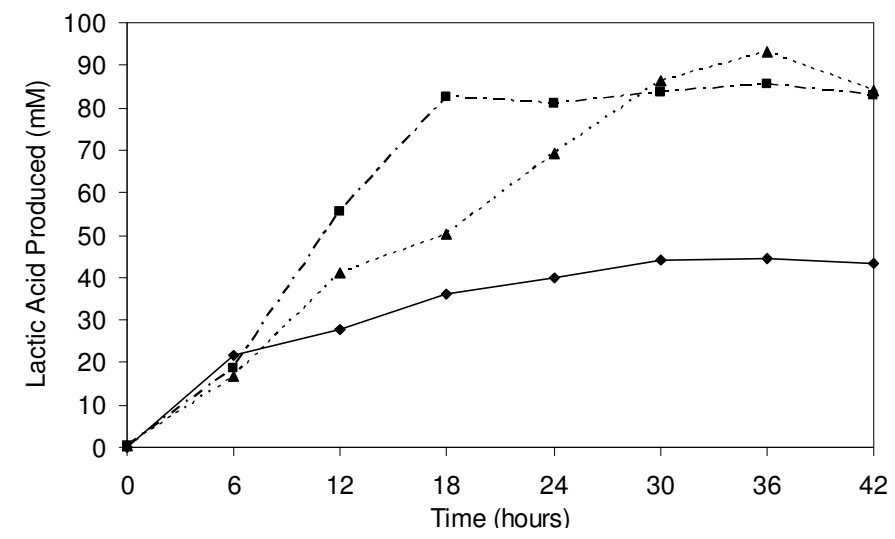

Figure 2. Lactic acid produced by three strains of Lactobacilli: ( $\bullet$ Spo05, (-) Spo04 and (A) Spo20 isolates over $42 \mathrm{~h}$.

acids could inhibit growth (Amrane and Prigent, 1999). On the other hand, all the isolates except Spo20, lactobacilli, could grow in alkaline environment, $\mathrm{pH} 9$. Rhee and Pack (1980) observed that Lactobacillus bulgaricus also could not tolerate high $\mathrm{pH}$.

\section{Growth and lactic acid production profiles}

In the first $4 \mathrm{~h}$, Spo05, the lactococci strain, grew faster than Spo04 and Spo20, the lactobacilli strains, based on cell dry weight (cdw) measurements. After this, the growth of Spo5 leveled off at about $1.8 \mathrm{~g} / \mathrm{l} \mathrm{cdw}$ while Spo04 and Spo20 continued to register biomass increase until $19 \mathrm{~h}$ before their growth too leveled off at around 3.4 and $2.8 \mathrm{~g} / \mathrm{l} \mathrm{cdw}$, respectively (Figure 1). The low biomass produced by Spo5 with respect to Spo04 and Spo20 correlated well with the lower amount of lactic acid produced by Spo05 (Figure 2) resulting in a higher $\mathrm{pH}$ in the medium (Figure 3 ) and lower consumption of glucose (Figure 4). These results were consistent with those shown in Table 2 where Spo5 was found to be unable to tolerate high lactic acid concentrations and low pH com-

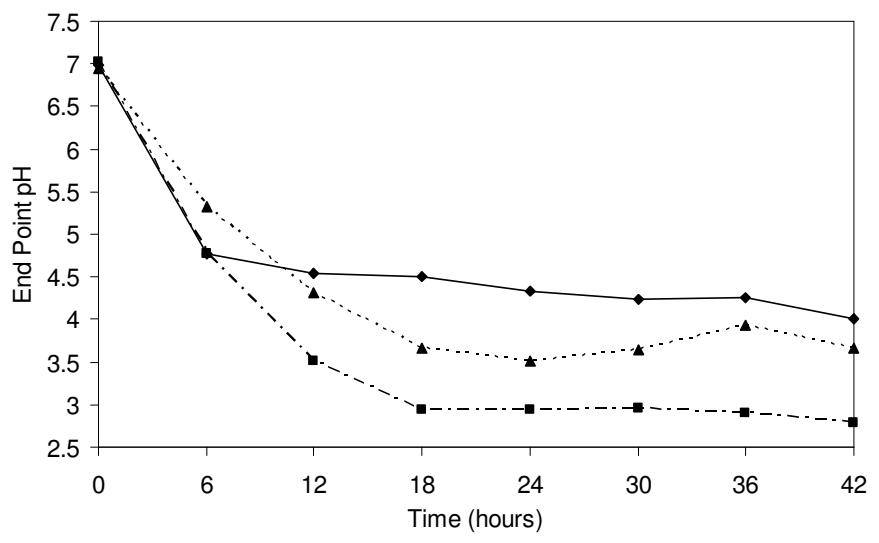

Figure 3. $\mathrm{pH}$ of the cultures of three strains of Lactobacilli: ( $\bullet$ Spo05, (匹) Spo04 and ( $\mathbf{\Delta}$ ) Spo20 isolates over $42 \mathrm{~h}$.

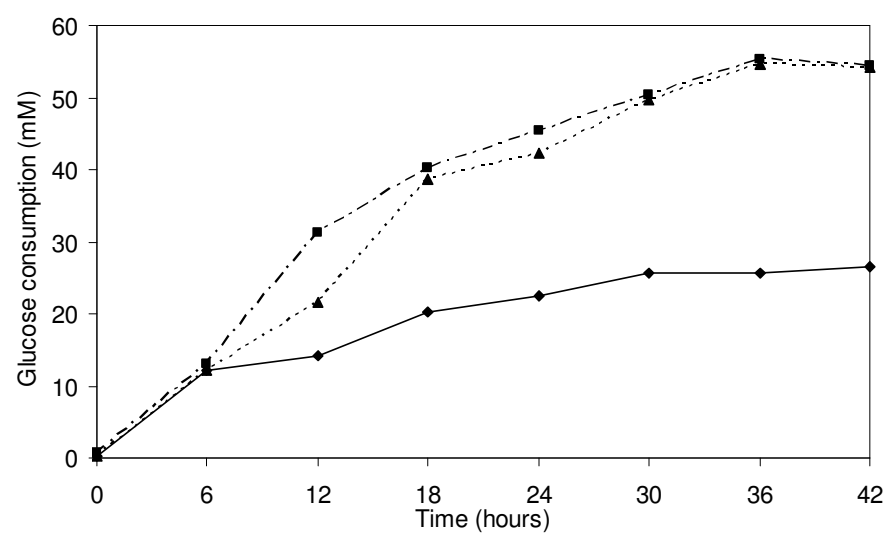

Figure 4. Glucose consumption $(\mathrm{mm})$ by three strains of

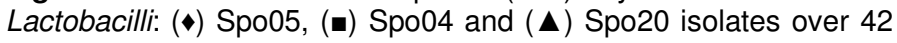
h.

compared to Spo04 and Spo20. While the growth profiles of Spo04 and Spo20 did not appear to be different from one another (Figure 1), the amount of lactic acid produced by Spo4 was higher than Spo20 for the first day, $24 \mathrm{~h}$ (Figure 2). The production of lactic acid by Spo20 also peaked faster at $18 \mathrm{~h}$ compared to glucose consumption (Figure 4) of the two Lactobacilli strains, respectively. At $30 \mathrm{~h}$, the yield of lactic acid from glucose was highest with Spo04 at 1.9, followed by Spo20 at 1.6, and Spo5 at 1.5. This indicated that Spo04 had the highest efficiency in converting glucose to lactic acid. Spo04 and Spo20 had similar tolerance levels to high temperature (up to $42^{\circ} \mathrm{C}$ ), lactic acid concentration (7.5\%), $\mathrm{NaCl}$ concentration (5\%), and to low $\mathrm{pH}(5.5)$, but the faster production of lactic acid by Spo20 might give it a slight advantage over Spo4. This difference between Spo04 and Spo20 was apparent under current experimental conditions, i.e., using MRS medium in which glucose was the primary carbon source and the medium 
was not $\mathrm{pH}$-controlled. In developing the fermentation process to industrial level, cheaper sources of carbon are necessary and the medium would need to be $\mathrm{pH}$ controlled by incorporating neutralizing agents such as calcium carbonate into the medium to reduce the inhibitory effects of free lactic acid on the producer cells. Under such conditions, the growth and lactic acid production of Spo04 and Spo20 would need to be reevaluated.

The time-course study was conducted to compare the growth and lactic acid producing capacity of two lactobacilli strains and a lactococci strain, the findings of which supported the results of the rapid screening tests on tolerance of the strains to a range of environmental factors. There was little doubt that the amount of biomass and lactic acid produced by the respective strains were limited by the accumulation of lactic acid in the fermentation broth and the prevailing $\mathrm{pH}$, and reflected the different tolerance levels of the strains. $\mathrm{A} \mathrm{pH}$ controlled medium would probably allow for higher accumulation of lactic acid and would be appropriate for future studies where optimization of the fermentation process was the focus.

\section{Optical isomer of lactic acid comparison}

$L(+)$-Lactic acid is more important for pharmaceutical and food industries; therefore produced lactic acid was used for optical isomers determination. This was examined by lactate dehydrogenase kit enzyme test. The results of optimum isomers of lactic acid produced by best strains are shown in Figure 5 .The basic difference between this group $L$. casei, $L$. lactis and the other $L$. plantraum and L. paraplantarum fermentation is that only the form $L(+)$-lactic acid is produced, whereas the latter fermentation is anaerobic and $L(+)-, D(-)-$, DL-lactate is produced. The purity of monomers is highly critical in the synthesis of polylactides and a purity of $99 \%$ or greater is usually required with the starting lactide material (Lewis, 1991). Among Lactobacilli strains, L. casei subsp casei produced high concentration of $L(+)$-lactic acid with $98 \%$ purity. Other Lactobacilli strains produced combination of both optical isomers. This confirmed experimental work of Vaccari et al. (1993).

\section{Conclusion}

This study described the sequential steps of isolating bacteria from south African poultry farms (Senegal), screening the isolates for $L A B$ traits, selection of isolates based on a series of tests for industrially-desirable traits, and finally compared the growth and lactic acid production profiles between the lactobacilli and lactococci strains. In this study, the determination of optical active isomer producers of lactic acid in the fermentation broth and provides a complete profile of substrate utilization by these microorganisms.

\section{ACKNOWLEDGEMENTS}

The authors would like to acknowledge Mrs Maryse Hardenne and Mr Vincent Hote for their contribution. We thank all the technical personal of CWBI (Centre Wallon de Biologie Industrielle). We also like to express our gratitude to the Republic of Ivory Coast and the Communauté Française de Belgique for financial assistance.

\section{REFERENCES}

Amrane A, Prigent $Y$ (1999). Effect of the main culture parameters on the growth and production coupling of lactic acid bacteria. Appl. Microbiol. 2: 101-108.

De Man JC, Rogosa M, Sharpe ME (1960). Medium of Lactobacilli. J. Appl. Bacteriol. 23: 130-135.

De Vos WM, Kleerebezem M, Kuipers OP (1997). Expression systems for industrial Gram-positive bacteria with low guanine and cytosine content. Curr. Opin. Biotechnol. 8: 547-553.

Drancourt M, Bollet C, Carta A, Rousselier P (2001). Phylogenetic analyses of Klebsiella species delineate Klebsiella and Raoultella gen. nov., with description of Raoultella ornithinolytica comb. nov., Raoultella terrigena comb. nov. and Raoultella planticola comb. nov. Int. J. Syst. Evol. Microbiol. 51: 925-932.

Gasson MJ (1993). Progress and potential in the biotechnology of lactic acid bacteria. FEMS. Microbiol. Rev., 12: 3-20.

Gibson T, Abdel-Malek T (1945). The formation of carbon dioxide by lactic acid bacteria and Bacillus licheniformis and a cultural method of detecting the process. J. Dairy. Res. 14: 35-44.

Glaasker E, Tjan FSB, Steeg PFT, Konings WN, Poolman B (1998). Physiological response of Lactobacillus plantarum to salt and nonelectrolyte stress. J. Bacteriol. 180: 4718-4723.

Gonzalez CJ, Encinas JP, Gracia-Lopez ML, Otero A (2000). Characterization and identification of lactic acid bacteria from freshwater fishes. Food Microbiol. 17: 383-391

Greetham H, Greetham L, Glenn R, Gibson CG, Hans H, Birgit M, Ulrike S, Enevold F, Matthew DC (2003). Clostridium colicanis sp. nov., from canine faeces. Int. J. Syst. Evol. Microbiol. 53: 259-262.

Hutkins RW, Ellefson WL, Kashket ER (1987). Betaine transport imparts osmotolerance on a strain of Lactobacillus acidophilus. Appl. Environ. Microbiol. 43: 2275-2281

Kandler O, Weiss N (1986). In: Bergey'sManual of Systematic Bacteriology. Sneath PHA, Mair NS, Sharpe ME, Holt JG (Eds), Vol. 2, Baltimore: Williams and Wilkins, pp.1209-1234.

Kashket ER (1987). Bioenergetics of lactic acid bacteria: Cytoplasmic $\mathrm{pH}$ and osmotolerance. FEMS. Microbiol. Rev. 46: 233-244.

Kharras GB, Sanchez-Riera F, Severson DK (1993). Polymers of lactic acid. In: Molby, D.B. (Ed.), Plastics from microbes: Microbial synthesis of polymers and polymer precursors. Hanser Publ., pp. 93-137.

Lewis DH (1991). Controlled release of bioactive agents lactide/ glycolide polymers. In: Polymers as drug delivery systems. (Chasin, M. and Langer, R. eds.), Dekker Inc, New York, pp. 1-41.

Mayra-Makinen A, Bigret M (1998). Industrial use and production of lactic acid bacteria. In Lactic Acid Bacteria. Microbiology and Functional Aspects, 2nd. (eds)S. Salminen \& A. V. Wright. New York: Marcel Dekker. pp. 73-102

Mollet B (1999). Genetically improved starter strains: opportunities for the dairy industry, Int. Dairy. J. 9: 11-15.

Monteagudo JM, Rodriguez L, Rincon J, Fuertes J (1997). Kinetics of lactic acid fermentation by Lactobacillus delbrueckii grown on beet molasses. J. Chem .Tech. Biotech. 68: 271-276.

Nakayama O, Yanoshi M (1967). Spore-bearing lactic acid bacteria isolated from rhizosphere. I. Taxonomic studies on Bacillus laevolacticus nov. sp. and Bacillus racemilacticus nov. sp. J. Gen. Appl. Microbiol. 13: 139-153.

Reid G (1999). The scientific basis for probiotic strains of Lactobacillus. Appl. Environ. Microbiol. 65: 3763-3766.

Ringoe E, Gatesoupe FJ (1998). Lactic acid bacteria in fish: a review Aquaculture. 160: 177-203. 
Rhee SK, Pack MY (1980). Effect of environmental pH on fermentation balance of Lactobacillus bulgaricus. J. Bacteriol. 144: 217-221.

Sanders W, Gerard V, Jan K (1999). Environmental stress responses in Lactococcus lactis. FEMS. Microbiol. Rev., 23: 483-501.

Schleifer KH (1987). Recent changes in the taxonomy of lactic acid bacteria, FEMS. Microbiol. Rev.46: 201-203.

Sghir A, Gramet G, Suau A, Rochet V, Pochart P, Doré J (2000). Quantification of bacterial groups within human fecal flora by oligonucleotide probe hybridization. Appl. Environ. Microbiol. 66: 2263-2266.

Siebold M, Frieling PV, Joppien R, Rindfleisch D, Schugerl K, Roper H (1995). Comparision of the production of lactic acid by three different Lactobacilli and its recovery by extraction and electrodialysis. Process. Biochem. 30: 81-95.

Stiles ME, Holzapfel WH (1997). Lactic acid bacteria of foods and their current taxonomy Int. J. Food. Microbiol. 36: 1-29.

Uguen P, Hamelin J, Le Pennec J, Blanco C (1999). Influence of osmolarity and the presence of osmoprotectant on Lactococcus lactis growth and bacteriocin production. Appl. Environ. Microbiol. 63: 291293.
Vaccari G, Gonzalez-Vara YRA, Campi AL, Dosi E, Brigidi P, Matteuzzi D (1993). Fermentative production of L-lactic acid by Lactobacillus Casei DSM 20011 and product recovery using ion exchange resins. Appl. Microbiol. Biotechnol. 40: 23-27.

Wouters JA, Kamphuis HH, Hugenholtz J, Kuipers P, De Vos WM, Abee $T$ (2000). Changes in glycolytic activity of Lactococcus lactis induced by low temperature. Appl. Environ. Microbiol. 66: 3686-3691. 